\title{
A Study of the Enzyme-secreting Cells in the Seedlings of Zea Mais and Phoenix dactylifera?
}

\author{
BY \\ HOWARD S. REED, \\ Instructor in Botany in the University of Missouri.
}

With Plate $\mathbf{X X}$.

I. HISTORICAL.

THE morphology and physiology of secreting-cells offer an inviting 1 field for study. Their metabolism is more active and continues for a longer time than that of embryonic tissue. The constant removal of the products of synthetic activity affords opportunity for observing the changes which accompany their production. Some of the most instructive descriptions of these cells have been given by students of animal histology, the highly specialized glands of animals affording a favourable subject for investigation. A brief résumé of the most important contributions to our knowledge of the subject is here given.

Charles Darwin ('75) described the changes occurring in the stimulated gland-cells of Drosera rotundifolia during the process of digestion. His experiments were carried farther by his son, Francis Darwin ('76, '77, '78), using Drosera rotundifolia and Dipsacus fullonum. Following their work came that of Schimper ('82) on Sarracenia, Drosera, and Utricularia; Fromann ('84) on the glandular hairs of Pelargonium; and de Fries ('86) on Drosera. The first detailed cytological study of secreting-cells in plants was that of Gardiner ('85) on the gland-cells in the tentacles of Drosera dichotoma. He saw that the process of secretion was accompanied by vacuolization and destruction of the cytoplasm in the distal end of the cell, but the nucleus was always surrounded by a dense layer of protoplasm. His explanation of the process of secretion was that the cytoplasm contains a 'formed substance' derived from the protoplasm, and that the out-pouring of the secretion is caused by the repeated breaking down of the protoplasm into this 'formed substance,' which is of a mucous nature and, attracting water, escapes as the secretion to the external surface.

${ }^{1}$ LXX. Contribution from the Botanical Laboratory of the University of Michigan.

[Annals of Botany, Vo1. XVIII. No. LXX. April, 1904.] 
Korscheldt ('89) studied the gland-cells in the genital organs of Branchipus and in the glands of butterfly larvae. He found that the nuclei moved to the apex of the cells during active secretion and returned to the base during the resting period of the gland; and concluded that the position of the nucleus in a cell indicates a participation in the activities at that place. In some cases where he thought that solid granules pass from the nucleus into the cell, there was apparently a direct change from nuclear substance into secretion, but he was not sure of the identity of the substances thus produced from the nucleus. During secretion, amoeboid movements were frequently observed in the nuclei.

The results of Muiller ('96), ('98) are very instructive, especially as to the extra-nuclear processes connected with the production of secretions.

The first detailed cytological study of secreting-cells in the botanical realm was on the effect of stimulation of the glandular-cells of Drosera with egg-albumen by Miss Huie ('97), and a later paper ('99) by the same author on the effect of stimulation with substances of various composition. She found that the cytoplasm, which in the resting stage is abundant and stains blue with Mann's Eosin-Toluidin blue, is exhausted by the process of secretion and shows strongest affinities for the red stain. During the period in which the secretion is being formed there is a constant increase in the amount of chromatin in the nucleus accompanied by a decrease in the size of the nucleolus. By the use of chemically different stimuli, very characteristic alterations are obtained in the morphology and colourreactions of the cell. The cytoplasm is the cell-constituent most noticeably affected by external stimuli, but the nucleus is said to be the seat of metabolic activity. In all cases the process of recuperation begins in the nucleus. She concludes that the rate of plasmic changes depends on the rate of absorption, but that the rate of nuclear changes is commensurate only with the digestibility of the food.

Rosenberg ('99) has given a very accurate and valuable description of the cytological changes accompanying the stimulation of the gland-cells of Drosera rotundifolia, making comparisons between the secreting-cells and the reproductive-cells of that plant. $\mathrm{He}$ gives the following interesting observations on the behaviour of the nucleus. The volume of the nucleus constantly grows smaller during secretion; the chromatin shows a constant increase. At first the chromatin is in the form of granules on the nodes of the linin network throughout the nucleus. Gradually the granules collect at the nuclear membrane, where they fuse into longer or shorter rods ; finally, when the effect of the stimulus is particularly energetic, these rods unite and form a single thread with richly anastomosing branches. When the digestive process is ended the thread gradually becomes thinner, and here and there segments, until finally the original condition of the nucleus is reached. In certain cases where the leaf is very strongly stimulated and the feeding 
process lasts for a long time, the chromatin content increases farther and chromatin granules lie within the interior of the nucleus. Simultaneous with these changes the nuclear membrane becomes indistinct, and at times almost invisible. Miss Huie reported the same appearance and expressed the belief that the nuclear membrane was absorbed. Rosenberg believes that the membrane undergoes a change in composition and staining qualities which perhaps facilitates the communication between nucleus and cytoplasm. The nucleolus constantly grows smaller until at the close of secretion it is very small. Yet he thinks there is no close connexion between nucleolus and chromatin, for there are nuclei with abundant chromatin which nevertheless contain large nucleoli. Chromatin is apparently an active component of the nucleus, yet it remains an open question whether the increase of chromatin is the result of the formation of an enzyme, or of the abundant absorption of nutrition. He thought that the latter theory was improbable.

In his work on the secreting-cells of the pancreas, Mathews ('99) found that during secretion the nucleus moves nearer the centre of the cell and that the fibrillar zone increases in size, while the granular and reticulate cytoplasm disappears. The granules called zymogen-granules arise as products of the decomposition of the threads which in turn are formed by the chromatin. Neither the nucleoli nor chromatin showed any periodic alteration in amount or staining reactions. The synthetic processes in the nucleus were thought to resemble in many ways catalytic or fermentative actions.

Another interesting and careful study is that of Garnier ('00) on various animal glands, but his results are not different from those already given.

While my work was still in progress, Torrey ('02) published an account of the cytological changes occurring in the cells of the scutellum of Zea Mais during the secretion of enzyme. His observations and conclusions differ from mine in many important respects, as I shall show later.

He locates the origin of the diastase granules in the nucleus, where they exist as fine, deeply-staining granules. From the nucleus, fine rows of granules extend through the nuclear membrane and out into the cytoplasm. After germination has progressed for about eighteen hours the cells are much larger than in the resting stage, the nuclei are for the most part devoid of granules, which are now to be found in the cytoplasm. After twenty-four hours certain cells are to be found in which the granules are massed together in the ends nearest the endosperm, but otherwise the cytoplasm and nuclei are entirely destitute of them. At the beginning of the second day of germination the secreting-cells are in a resting condition; there is no increase in size and the nuclei are clear.

The second period of secretion begins at the end of the second day. It is indicated by the presence of darkly staining granules in the nucleus 
and their subsequent discharge. After seventy-two hours the periods of secretion are not well marked. At the end of eleven days there are signs of degeneration in some of the epithelial cells as indicated by an abnormal swelling and vacuolization of the cytoplasm. After twenty-two days the cytoplasm is very scanty.

\section{MATERIAL AND Methods.}

In my work I have attempted to study the morphology of the enzymesecreting cells in the scutellum of $Z e a$ Mais and in the 'absorbing organ' of the seedling of Phoenix dactylifera.

It has been proved by the work of Brown and Morris ('90), Hansteen ('94), and Grüss ('97) that the diastase produced by the scutellum of the Gramineae is formed and secreted by the columnar epidermal cells of that organ. In Phoenix dactylifera the production and secretion of enzymes occurs in the columnar epidermal cells of the absorbing organ (Grüss, '94, Puriewitsch, '98). It is to a consideration of the morphological changes that this paper is devoted; the physiological changes will be made the subject of a subsequent study. My work was carried out at the Botanical Laboratory of the University of Michigan during the years 1902 and 1903. It is with great pleasure that I take this opportunity of expressing my thanks to Professor F. C. Newcombe for his invaluable suggestions and criticisms.

I used the large variety of $Z e a$ Mais known in agriculture as 'White Dent,' and the seeds of Phoenix dactylifera obtained from the dates of commerce. The resting embryos were cut from the dry seeds and killed in strong alcoholic killing fluids. The embryos of different ages were obtained by germinating the seeds in moist sawdust or between layers of moist filter-paper. Light was always excluded in order to prevent any manufacture of food by photosynthesis. The embryos of Phoenix were grown in an incubator at a temperature of $30^{\circ} \mathrm{C}$., those of Zea were grown at a temperature of $22^{\circ}$ to $25^{\circ} \mathrm{C}$.

The study of fixed and stained material was supplemented by that of living cells in both plants. Sections of the living material were cut with a razor and mounted in water, or in dilute sugar-solution if they were to be studied for any length of time. Methylene blue in aqueous solution was used for intra vitam staining. In many respects the use of living material was not as satisfactory as one would expect, owing to the difficulties in identifying the different substances in the cell. It was, nevertheless, valuable as a check on the artificial appearances produced by killing fluids and other reagents. It is well known that certain methods of fixing and staining give characteristic appearances to the tissues upon which they are used, especially upon cells containing large amounts of plastic material in a fluid state. Many of the discrepancies between the descriptions of different investigators are doubtless due to different processes of fixing and 
embedding. An interpretation of the effects produced awaits an extension of our knowledge of the chemical and physical reactions between protoplasm and the various reagents used in micro-technique.

In order to obviate as far as possible particular effects due to chemical or physical action of the killing fluids, a number of different fluids were used and different stains employed after each method of fixing. The technique was rather difficult on account of the delicacy of the material. The following results were observed with the respective killing fluids.

Saturated Solution of Picric Acid in 50 per cent. Alcohol. The material prepared for study by this reagent was unsatisfactory. The protoplasmic structures were not fixed well enough to show with any definiteness. On the other hand, this is a good reagent for fixing the proteid granules. (Zimmermann, '93, p. 216.)

Aqueous Picro-corrosive Fluid. I used the following modification of Mann's method as given by Huie ('97). One volume of a saturated aqueous solution of mercuric bichloride was added to three volumes of a saturated aqueous solution of picric acid. The material was allowed to lie in this fluid for twelve to eighteen hours, then washed in water and dehydrated in the usual way with alcohol. This proved to be a very satisfactory killing fluid. The amount of picric acid present was sufficient to fix perfectly the granules, while the mercuric bichloride hardened the protoplasm and precipitated the soluble proteids. In a few cases there was a tendency to contract the cell-contents in the scutellum of $Z e a$.

Kleinenberg's Picro-sulphuric Acid. The results obtained by the use of this reagent indicated that it was better than picric acid alone, but not so good as the picro-corrosive fluid. The material seems to be insufficiently hardened.

Chromo-Osmo-Acetic Acid. Mottier's formula, Pring. Jahrb. Bd. $3^{\circ}$, p. I70. This fluid is a good fixing agent for the protoplasmic structures of the cell, but not for the granular structures. It produced no shrinking in any of the cases where it was used.

Iridium chloride in Acetic Acid. The formula used was-

Iridium chloride I per cent. aqueous solution . $\quad 25 \mathrm{cc}$.

Glacial acetic acid . $. \quad . \quad .75 \mathrm{cc}$.

It leaves the tissue in better condition for the stain than the following killing fluid, but in other respects the two act similarly.

Worcester's Killing Fluid. This fluid gave uniformly good results whenever used. The formula according to which it is made is as follows :-

Mercuric bichloride, saturated aqueous solution . $9^{6}$ parts.

Formalin (40 per cent. formaldehyde) . . . . 4 "

Acetic acid, Io per cent.

Formic acid, to each litre of solution . . . 5 drops. 


\section{Reed.-A Study of the Enzyme-secreting Cells in the}

The tissue is allowed to remain in the killing fluid from ten to twenty hours, then transferred for washing to 70 per cent. alcohol, which contains about I per cent. of potassium iodide. If the killing fluid is not completely removed, it interferes with the action of the stains, more particularly the basophil stains.

Probably the good results obtained with this reagent are due to the large amount of soluble chloride it contains, which precipitates the proteids in the cells.

Saturated Solution of Mercuric Bichloride in Absolute Alcohol. This reagent was used to kill resting embryos in the dry seeds, where the presence of air in the tissues hinders the penetration of heavy liquids. It produced good preparations, but did not leave the nuclei of the cells as susceptible of staining as Worcester's fluid.

It will be seen from the foregoing accounts that the killing fluids which gave the best results were those containing a large proportion of soluble chloride and a small proportion of acid. Those fluids which contained a large proportion of acids appeared to have a corrosive action upon the proteid granules in the cells. In small amounts the presence of acids appeared to facilitate the penetration of the reagent without corroding the granules.

Most of the material was embedded in paraffin by the ordinary method. In the case of dry seeds I used a method for which I am indebted to Mr. B. J. Howard ('03). By the use of this method I completely infiltrated the pieces of seeds (which were always small) with paraffin, and succeeded in obtaining uniformly good preparations.

The results obtained by the use of different stains were as variable as those of the different killing fluids. No one stain could be depended upon in all cases. The use of stains is twofold - to render the objects more opaque for study, and to give an indication of their acidity and alkalinity. While I did not find it possible to apply the terms 'cyanophil' (basophil) and 'erythrophil' (eosinophil) with precision, yet the absorption of different stains serves in a general way to indicate the nature of cell-contents. The use of the different stains gave the results described below.

Picro-Nigrosin. This was found to be a very satisfactory stain for general cytological purposes. It brings out the granules, nuclei, and cytoplasts very plainly, but does not give them a differential stain.

Kleinenberg's Haematoxylin. The results obtained by the use of this stain were much the same as the preceding. It is a very valuable stain for chromatin, and was used chiefly on that account.

Haidenhain's Iron Alum Haematoxylin. The method described by Torrey ('02), using Congo Red as a counter-stain, was employed. It is a very valuable stain when used in connexion with others, but cannot be 
relied upon when used alone. It gives no indication of the acidity or alkalinity of the cell-contents, nor does it differentiate the granules in the cytoplasm from those in the nucleus.

Zimmermann's Fuchsin-Iodine-Green. Repeated attempts with this otherwise valuable stain were not successful in producing a single good preparation. The stain seems to have no affinity for the granules, and not even the protoplasmic structures were stained satisfactorily.

Anilin-Gentian-Violet-Iodine-Eosin. Gram's Method. The sections were not stained deeply enough when this stain was used to afford any satisfactory study.

Mann's Eosin-Toluidin Blue. This proved to be the most valuable stain used, and was employed more extensively than any other in my work. The method described by Huie ('97) was employed in staining the sections. It not only differentiates cell-walls and cell-contents, but differentiates one kind of granules from another in the same cell. The cell-walls were stained blue; starch-grains were stained bluish-green; cytoplasm, blue (red in cells where secretion had progressed for some time); zymogen granules, blue (or purple); chromatin, reddish-purple. The best results were obtained in material which had been fixed by Mann's aqueous picro-corrosive killing fluid.

Eosin and Anilin Blue. This stain was used to good advantage with sections of $Z e a$, where a differentiation of starch- and proteid-grains was desired.

Eosin and Gentian Violet. The same methods were employed with this stain as for the two preceding, but it did not give as good results. The cell-contents were not plainly differentiated.

Flemming's Triple Stain. Good preparations were obtained by the use of this stain, but it did not differentiate the different granules in the cell sufficiently to make it a valuable stain. It works best after the use of Chromo-osmo-acetic acid, but does not give good results after the use of fluids containing mercuric bichloride.

\section{ObSeRvations on the Scutellum of Zea Mais.}

A cross-section of the scutellum, when examined under the microscope, is seen to consist of large, nearly isodiametric cells, which are bounded on the side next the endosperm by a single layer of columnar epidermal cells. There is not only a noticeable difference in the size and shape of the two kinds of cells, but also in their contents. The granules found in the epidermal cells are always small, and are composed of proteid; the granules in the large cells of the scutellum may be either starch or proteid; and the proteid may be in the form of large or small granules. 


\section{A. Studies on Living Material.}

Twenty-four hours old. The protoplasmic body of the epidermal cells of the scutellum still shows the characteristics of the resting condition; it does not entirely fill the cell-cavity. The cells contain a large amount of granular substance which is coloured yellowish-brown by iodine. The underlying cells of the scutellum contain two kinds of granules-proteid and starch.

Two days old. The cells of the epidermal layer are still closely packed with fine granules, but the larger proteid granules have disappeared from the underlying layers of cells. The nuclei of the epidermal cells, where observable, present an uneven contour. The scutellar cells in the vicinity of the plumule contain a small amount of starch.

Three days old. This lot of seeds had made rapid growth; when the embryos were removed for study the radicles were $\mathrm{I} \cdot 5$ to $2.5 \mathrm{~cm}$. long, but the condition of the secreting-cells was only slightly more advanced than that described for the second day. The epidermal cells were full of small proteid granules, but the large proteid granules had disappeared from the first three or four layers of hypodermal cells. There was again an evident accumulation of starch about the plumule.

Four days old. The radicles of this lot of seeds only average $\mathrm{I} \mathrm{cm}$. in length, but the cytological changes in the scutellum are farther advanced than in the last set. The epidermal cells contain proteid granules only in the distal ${ }^{1}$ half or third of the cell. A few cells are entirely free from granular material.

Seven days old. Cotyledons $\mathrm{I} \mathrm{cm}$. long, radicles $2 \mathrm{~cm}$. long. The epidermal cells are nearly free from granules. In those cells where granules are found they are small, and occur only in the distal end of the cell. The scutellar cells have lost all of the large proteid granules, but still contain large numbers of the small granules. In favourable cases the vacuolate protoplasm may be seen. When the small granules of the epidermal cells disappear, the small granules of the scutellar cells, which in their turn have probably resulted from the disintegration of the large granules, also begin to disappear.

The cells of the scutellum show an increasing amount of starch in the region of the plumule. After the application of iodine to the sections the consequent darkening can be seen plainly by the naked eye. The presence of this starch has two possible explanations-it may arise indirectly from the breaking down of proteid matter in the scutellum (cf. Timberlake, '01), or it may be formed by the anhydration of some soluble carbohydrate derived from the endosperm.

${ }^{1}$ In the subsequent descriptions of epidermal cells, the term 'distal' refers to the end of the cell in contact with the endosperm, ' proximal' refers to the opposite end. 
Nine days old. Nearly all the epidermal cells are devoid of granular material; the remainder contain granules evenly distributed throughout the cytoplasm. The starch in the vicinity of the plumule is beginning to disappear. The substance of the endosperm is almost completely dissolved and absorbed at this time. Apparently the epidermal cells of the scutellum have ceased to be actively secreting cells and are now principally vegetative in function. A little later the contents of these cells disappear; possibly they are absorbed by the growing plant.

\section{B. Studies of Microtome Sections.}

Cells in the Resting Condition. The protoplasm of the epidermal cells is contracted away from the lateral walls and often from the distal wall of the cell. With a low magnification the protoplasm appears as a fine granular substance, homogeneous throughout. In a number of the cells there are irregular vacuoles in the proximal end of the cell. With higher magnification one can distinguish the granules arranged on the protoplasmic network.

There is no regularity as to the position of the nucleus in the cell at this time. It has a slightly irregular, elliptical outline. The nucleus contains fine granular material which renders it darker than the cytoplasm. There is only a small amount of chromatin present, and it occurs in the form of small spheres at the surface of the nucleus. These can be distinguished easily from the other granular material, because the latter appears to be evenly distributed throughout the interior of the nucleus, while the chromatin is at the surface. The faint outline of a nucleolus may be distinguished in favourable sections. (Plate XX, Fig. I.)

The other cells of the scutellum are so densely filled with granules of proteid matter that none of the protoplasmic structures are visible except the nucleus.

Cells after imbibition with water for three hours. The contents of many of the epidermal cells do not yet completely fill the cell-cavity (Fig. 2). The cytoplasm is full of small, flocculent granules which stain blue with Mann's Eosin-Toluidin Blue. The nucleus contains two kinds of nucleo-proteid matter in the form of granules. Undoubtedly the larger granules are chromatin and the smaller ones may be a reserve product stored in the nucleus; because as the cell-metabolism proceeds these fine granules rapidly disappear from the nucleus. The nucleolus stains red, the chromatin and fine granules, dark purple.

The large isodiametric cells of the scutellum are completely filled with two kinds of granules at this stage, a number of large and small proteid grains which nearly fill the cell and stain red with Mann's EosinToluidin Blue, and larger spherical starch grains which stain blue. 
Condition of the scutellum after thirty hours of activity (Fig. 3). The cells of the epidermal layer are noticeably larger than those in the stage last studied, and are completely filled with granular protoplasm, which is slightly denser at the distal end of the cell and stains purple with Mann's Eosin-Toluidin Blue. The granules show some conformity in their arrangement to the strands of the cytoplasmic network. The nuclei are of the sort one finds in cells where active metabolism is going on. Nearly every nucleus is surrounded by a vacuole and lies in the proximal end of the cell. The karyolymph, or nuclear plasm, contains, as in the last stage, two kinds of material. However, there is much less of the fine granular material than in any preceding stage, and the larger bodies of nucleo-proteid, chromatin, have increased in size. It can also be seen that the chromatin is arranged on the linin network. The nucleolus, although distinct, is not prominent. The staining properties of the granules in the cytoplasm indicate that they are of a different character from those in the nucleus; the former stain blue with Mann's Eosin-Toluidin Blue, the latter stain red. Part of the proteid granules have disappeared from the more deeply lying cells of the scutellum. There is a slight increase in the amount of starch in the scutellum, the greatest increase being near the plumule.

Morphology of the cells at the end of two days of activity. Radicles I $\mathrm{cm}$. long. There is a further decrease in the amount of the granular substance in the cytoplasm and an increase in the amount of chromatin in the nucleus (Fig. 4). The nucleolus is hardly to be distinguished because it has become smaller and lost most of its ability to absorb stain. The nucleus is usually located in the proximal half of the cell. The contents of the subepidermal cells of the scutellum are beginning to diminish. They are probably being used for the nourishment of the plant or to form enzymes.

Morphology of the cells at the end of the third day of activity. Temperature $25^{\circ}$. On the third day the scutellum appears to be secreting diastase very actively. The epidermal cells contain a fine granular substance which stains bluish-purple and contains embedded in it larger granules, which are of almost the same size as the chromatin granules of the nucleus, but differ from them in staining properties. This granular matter is quite evenly distributed throughout the cell, but is nowhere so dense as in the preceding stages.

The nuclei are at the middle of the cell or in the proximal half. The finely divided granular substance which was present in the nucleus has all disappeared at this stage, but the chromatin of the nucleus continues to increase. It exists in the shape of spherical and rod-like masses at the surface of the nucleus (Fig. 5). I have not seen any cases where I thought that solid particles were passing from the nucleus into the 
cytoplasm. On the contrary I think there is evidence that the nucleoproteids leave the nucleus in a fluid condition; because the nuclei at this stage have a swollen and distorted appearance (Fig. 6). In a few cases a vacuole surrounds the nucleus. A nucleolus is present in nearly every case.

Apparently some of the contents of the subepidermal cells are used in the formation of diastase, because those cells in the vicinity of the epidermal layer are showing more signs of depletion than any others; in fact those in the vicinity of the young plant show little sign of depletion. The content of starch has increased over any previous stage.

Morphology of the cells at the end of the fifth day of activity. At this time there is a still greater depletion of the granular substance in the cytoplasm of the epidermal cells, which causes it to appear lighter coloured in all instances. The greatest scarcity of granules is at the proximal end of the cells. The nuclei are large and contain a large amount of chromatin in the form of spherical masses at the surface of the nucleus. They show a difference from the last stage in being found no longer in the proximal half of the cell, but in the distal half, a short distance above the centre. The nucleolus has diminished in size until it is no longer visible. Apparently there is some relation existing between nucleolus and chromatin, because as one increases the other decreases. Some later experiments give more light on this subject. The same condition was found in Drosera by Rosenberg ('99), although there were numerous exceptions.

The morphology of the cells on the ninth day of activity (Fig. 7). The condition of the cells in the epidermis is quite similar to that described in the last stage, except it is very evident that increasingly greater quantities of proteid grains are disappearing. The nuclei are quite similar to those last described, both in appearance and position. The proteid granules which remain are most abundant in the distal end of the cell.

The morphology of the cells after thirteen days of activity (Fig. 8). The endosperm of the seeds from which this material was taken was nearly exhausted. The cytoplasm of the scutellar epidermal cells is compact and fills nearly the entire cell-cavity. It contains a small number of flocculent granules of a different sort from those appearing in the cells when enzymes are being actively secreted. The nuclei are situated near the centre of the cell. The nucleo-plasm stains but slightly different from the cytoplasm, making it difficult to determine the exact boundary between the two. Large nucleoli and a small amount of chromatin are the only substances which can be distinguished in the nuclei.

This condition of affairs suggests that the cells have ceased their active metabolism and are at this time in a passive state, and that perhaps even at this time a few have been partly absorbed by the growing plant. From this time on there is probably very little enzyme produced.

Taking a general survey of the morphological changes, we see that 


\section{Read.-A Study of the Enzyme-secreting Cells in the}

at first the cytoplasm of the secreting-cells contains fine, granular proteid material, which shows an affinity for basic stains. The nuclei of these cells contain finer granules, which stain differently from those in the cytoplasm and disappear much sooner. With the high power they can easily be distinguished from the chromatin. The amount of chromatin is small in the earliest stages, but the nucleoli are quite prominent.

At the beginning of the second day of activity the cytoplasm is densely filled with granular material, which is distributed on the cytoplasmic reticulations. A comparison of Figs. 2 and 3 will show the relative increase in size of the cell during the first day's activity. From this time forward there is a constant depletion of the granules of the cytoplasm, accompanied by a slow elongation of the epidermal cells. The nuclei are almost invariably nearer the proximal end of the cell. After two days of activity, one can notice that part of the starch of the endosperm has disappeared. In the nuclei of the epidermal cells there are two noticeable changes-a continued increase in the amount of chromatin and a decrease in the size of the nucleolus, which from this time forward is very inconspicuous.

The processes described above continue without much variation until the endosperm is exhausted. On the third or fourth day the nuclei move from their position in the proximal end of the cell toward the centre, and on the fifth or sixth day are found in the distal end of the cell (Fig. 7). The cytoplasm is nearly free from granules on the tenth day, and now shows an affinity for acid stains. Just before the final dissolution occurs, the cytoplasm of the epidermal cells becomes abundant and stains similarly to the nucleus.

\section{The Effect of Inhibited Growth upon the Secreting-Cells .}

Seedlings which had grown at a temperature of $23^{\circ} \mathrm{C}$. for fifty hours, and whose roots had attained a length of 3 to $4 \mathrm{~cm}$., were transferred to a temperature of $8-10^{\circ} \mathrm{C}$, after having removed and fixed a number of scutella. When they had remained twenty-four hours at the low temperature, the amount of growth shown by the roots was very small. At this time more material was removed and fixed in different killing fluids; the remaining seedlings were then placed at a temperature of $20^{\circ} \mathrm{C}$. for forty hours longer. At the expiration of this time the roots showed that growth was progressing normally again. The different lots of material were then sectioned and stained for microscopical study.

The sections showed that the cells of the epidermal layer were in an active condition when transferred to the cold room. They were full of fine granules, which stained blue with Mann's Eosin-Toluidin Blue. The densest accumulation of granular material was in the distal end of the cells. The nuclei, which were in the proximal end of the cell, contained chromatin in 
the form of fine granules. The nucleoli were spherical, well-defined bodies which stained dark purple.

After the growth had been checked by low temperature for twenty-four hours there was a marked change in the appearance of the cells. The cytoplasm contained large lumps which stain dark purple. The staining property of these aggregations was more intense than that occurring in ordinary secretion. The nuclei had lost most of their chromatic substance and appeared quite clear. They contained at least one large nucleolus which had lost neither in size nor staining qualities.

When normal conditions were restored, the cells appeared to regain activity. The fixed and stained material showed two things very clearly: (I) the aggregations had almost entirely disappeared from the cytoplasm, leaving it homogeneous purple; and (2) the nuclei contained numerous large granules of chromatin, but the nucleoli had disappeared. It hardly seems possible that any of the nucleo-proteids are absorbed by the nucleus when activity is resumed.

The fact that the nucleus contains granules only during resting periods, or periods of arrested growth, and is large, hyaline, and intimately connected with the cytoplasm during the time of most active secretion, indicates to my mind that the nucleus is not a storehouse of diastase in any form, but is the source of energy by which the diastase is produced. The view here taken is that the diastase is manufactured from other proteids and turned into secretion by the activity of the epidermal cells, in which processes the nuclei probably perform the largest part of the work.

My own work fails to confirm many of the observations made by Torrey ('02). I did not find, at the beginning of secretion, the nuclei filled with dark staining granules. Nor did I find the granules being extruded in a solid state into the cytoplasm through breaks in the nuclear membrane. There were, it is true, in the resting stage, fine granules in the nucleus; but they disappeared during the first two days and did not reappear. By far the greater amount of proteid granules was found in the cytoplasm of the epidermal and subepidermal cells before secretion began. Moreover, the granules in the cytoplasm differed both in size and staining qualities from those in the nuclei, and gradually disappeared as secretory activity progressed.

I likewise failed to find that the process of secretion in Zea is an intermittent one, in which periods of activity alternate with periods of rest. If the seedlings are grown at a constant temperature, the process of secretion is continuous while enzymes are being produced. In repeating Torrey's methods I found that the use of Iron Haematoxylin as a stain was the cause of many differences in our observations, because it is not reliable in differentiating the various cell-constituents. As his own paper states, it stains everything alike in a very deceptive manner, and is the cause of 
many artefacta in the sections. When part of the material was stained with Mann's Eosin-Toluidin Blue and part with Iron Haematoxylin, the resulting sections gave very different appearances. The preparations made with the former stain were relied upon because of their similarity to the sections of living cells.

\section{ObServations on the Absorbing Organ of Phoenix dactylifera.}

The absorbing organ is a button-shaped structure which is located in the date-seed on the side opposite the furrow. By means of the enzyme it produces, it dissolves the hard, ivory-like endosperm of the seed, and absorbs the soluble material for the use of the young plant. At first the absorbing organ is about the size of the head of a pin, but as germination progresses it enlarges and finally fills all the space formerly occupied by the endosperm. If we make a longitudinal section of this organ after the radicle has begun to protrude, it will be found to have a mushroom shape ; under the microscope it is seen to be composed of thin-walled parenchyma-cells with large intercellular spaces. In the radicle the cells are elongated, but they approach a spherical shape in the head of the absorbing organ. Near the margin of such a longitudinal section the cells are smaller and have contents different from the other cells. The entire surface of the head of the organ is covered by a layer of short, columnar cells.

\section{A. Studies of Living Material.}

Cells in the resting seed. The cells of the epidermal layer contain, in addition to the large spherical nuclei, fine hyaline granules in the cytoplasm. The other cells of the absorbing organ contain similar small granules and, in addition, numerous larger granules, all of which give the test for proteid with re-agents. The epidermal cells do not contain as much granular material as the other cells of the absorbing organ.

Observations upon seedlings five days old. At the end of this time the absorbing organ has increased to nearly twice its original size. The epidermal cells contain approximately the same amount of proteid matter as before, but in the form of larger granules. The nuclei of these cells are large and distinct, and each is at the centre of the cell.

Observations upon seedlings twelve days old. The radicles have not yet appeared outside of the seed. Except for continued enlargement, the sections of the absorbing organs are much the same as in the previous stage. The epidermal cells contain more proteid in the form of fine granules, but the nuclei are unchanged.

Observations upon seedlings twenty-two days old. The radicles of the seedlings average $2.5 \mathrm{~cm}$. in length. The epidermal cells of the absorbing organ 
have lost most of the granules which they contained in the previous stage. Those which remain are small and quite evenly distributed in the parietal layer of cytoplasm. The nucleus is smaller than in previous cases. It is situated near the centre of the cell, and connected to the lateral walls of cytoplasm by radiating strands. The deeper-lying layers of cells are nearly empty of granular material at this time. The elements of a fibro-vascular system are beginning to appear among the hypodermal cells.

Observations upon seedlings twenty-nine days old. The parts of the embryos outside the seed average $4 \mathrm{~cm}$. in length. The cells and cellcontents are much the same as in the last stage, except that they are more depleted of granular material. The granules which yet remain are nearly all confined to the epidermal and first hypodermal layers.

Observations upon seedlings thirty-three days old. The scanty granular material which yet remains in the cells of the absorbing organ exists in the form of large granules. Each epidermal cell contains a large vacuole surrounded by a thin layer of cytoplasm. The nuclei of these cells are smaller than in previous stages.

Observations upon seedlings fifty days old. The cells of the absorbing organ, both epidermal and hypodermal, are empty of granules, so far as can be ascertained by staining with iodine or methylene blue. The cytoplasmic body and nucleus retain the same size and relative position as in the previous stage.

\section{B. Studies of Microtome Sections.}

The morphology of cells in seedlings six days old (Fig. 9). There are very few changes from the condition which has been described for the resting stage in the living material. The epidermal cells of the absorbing organ show no elongation as yet. The cytoplasm contains a large amount of fine granular material which may represent the zymogen, because it disappears as enzymes are formed. The spherical nuclei, whose average diameter is about two-thirds the width of the cell, are usually situated near the centre of the cell. When stained with Kleinenberg's Haematoxylin, the chromatin is demonstrated as very small grains on the nodes of the linin network at the surface of the nucleus. The karyolymph does not contain granular matter as in the case of $Z e a$. A small nucleolus is present in each nucleus.

The morphology of cells in seedlings nine days old. The cells show certain well-marked changes from the conditions described in the preceding stage. The zymogen granules in the cytoplasm have not only increased in size, but in their affinity for stain. All the cells of the embryo are filled with proteid granules which stain more cyanophil than at any subsequent time. The densest accumulation of granules is in the hypodermal layers of cells. There is also a larger amount of chromatin present in the nucleus, the difference being due to an increase in the size of the 


\section{Reed.-A Study of the Enzyme-secreting Cells in the}

granules already present rather than to an increase in their number. The nucleoli show a slight increase in size.

The morphology of cells in embryos fourteen days old (Fig. 10). With the exception of a few layers of marginal cells, the granular contents of the absorbing organ have disappeared, and from this time forward there is no indication of metabolic activity in any except the surface-layers of cells. The epidermal cells are not only increasing in size, but numerous examples of karyokinetic division indicate that they are increasing in number. The staining reactions indicate that they are not so cyanophil as in the stage last described. The cytoplasm is beginning to show a diminution in the amount of granular material present. The finer granules seem to be the first to disappear. After their number has been diminished, it can be seen that the granules lie on the cytoplasmic network, not in its meshes.

The nuclear chromatin does not increase as fast with increased activity as in the case of Zea, yet there is an increase. The nucleolus, instead of diminishing, has up to this time retained its original size, and shows a strong affinity for stain.

The morphology of cells in seedlings eighteen days old (Fig. II). The cells are much the same, except for continued elongation, as in the preceding stage. Their staining qualities indicate that they are becoming more erythrophil.

The morphology of cells in seedlings twenty-six days old (Fig. I2). At this stage the cells of the absorbing organ are practically free from granular material. There are a few erythrophil granules in the marginal cells. The deeper-lying cells which originally contained proteid material have enlarged to several times their former size, and the protoplasm remaining forms a thin parietal layer. The elements of a vascular system have begun to make their appearance among the marginal cells of the absorbing organ.

There are three morphological differences between the nuclei of this and preceding stages-(I) they are smaller in volume; (2) the nucleoli are also smaller and often surrounded by a vacuole; (3) there is an increased amount of chromatin in the nucleus, which occurs in the form of small grains on the linin network at the surface of the nucleus.

The morphology of cells in seedlings thirty-three days old. At this age the absorbing organs are white elliptical disks about 8 or 10 $\mathrm{mm}$. diameter and $3 \mathrm{~mm}$. thick. The epidermal cells have lost much of the cytoplasm which they previously contained, many of them containing only a parietal layer. The most noticeable change is in the number of granules present in the cytoplasm (Fig. I3). It may be that part of the protoplasm has broken down to form an enzyme. The nuclei are not much smaller, but the nucleoli are diminished in size. The amount of chromatin is less also.

The morphology of cells in seedlings four months old. The seedlings from which the material for this study were obtained were grown in earth 
in the plant-house. At the end of four months $I$ found that the reserve cellulose of the seed was entirely consumed, and that the absorbing organ filled all the space occupied by the cellulose. The amount of cytoplasm in the cells is very small ; in none is there more than a thin parietal layer, and in many the nuclei have broken down and been absorbed. In the epidermal cells the amount of cytoplasm is very small. Strands radiate from the nucleus to different parts of the cell. The layer of cytoplasm on the distal wall is usually thicker than on the other walls. In some cells the cytoplasm has begun to break down into a disorganized mass of granules.

The nuclei, situated in various parts of the cell, have a smooth hyaline appearance and are devoid of chromatin. They still have a small, distinct nucleolus, which is about the same size as when activity began. The whole condition of affairs suggests that the cells no longer possess the function of actively secreting enzymes, but are now breaking down and being absorbed by the growing plant. The cells in the centre of the absorbing organ were the first to disappear, but the process of dissolution goes on until finally the epidermal cells are reached.

Taking a general view of the changes in the secreting-cells in Phoenix, we first find them short and thick, containing large spherical nuclei and densely granular cytoplasm which is distinctly basophil. During the first five or six days the cells increase in size, due to the absorption of water, but the contents show scarcely any change in composition. When secretion begins, the nuclei contain small granules of chromatin and small nucleoli. As secretion progresses they increase in size slowly until near the end of the third week; then the nucleoli begin to diminish, followed a little later by the chromatin granules. The cells and their contents are strongly erythrophil at this stage, and the proteid granules have nearly disappeared from the cytoplasm. The cytoplasm itself begins to disappear at the end of the fourth week, and finally the cells contain only a disorganized mass of substance.

It is quite evident that if my observations have been correct there are some differences between the secreting cells of $Z e a$ and those of Phoenix. The nuclei of the epidermal cells in Zea contain, at the beginning of activity, varying amounts of granular substance which soon disappear, leaving only the chromatin and the nucleoli. The nuclei of similar cells in Phoenix show no such substance.

The position of the nucleus in the cells of the epidermal layer is different in the two cases. In Phoenix it is almost always found at the centre of the cell; in Zea it moves to the distal end of the cell as the activity of secretion progresses.

It may be that the behaviour of the nucleus in the latter instance is in accord with the views of Haberlandt ('87), Townsend ('97), Harper ('99), and others, that the nucleus is usually situated in that part of the cell where the most active metabolism occurs. But nothing definite can be stated 
until more plants have been examined. The behaviour of the nuclei in Phoenix appears to contradict any assumption which could be made concerning Zea.

The nuclei in the two plants increase in size for a time as germination progresses. In Phoenix this increase ceases when the embryo is but a few centimetres long, and the nucleus then appears to become smaller, though it is probable that enzyme-formation is greater after the nucleus beginstodiminish. The nuclei may increase in size merely because the cells increase in size.

There are also differences in the behaviour of chromatin and nucleoli in the nuclei of the two plants. In $Z e a$ the nucleoli are large when the activity of secretion begins, and diminish in size as it progresses until they are no longer visible. The quantity of chromatin, on the other hand, increases as the nucleoli diminish. In Phoenix the nucleoli are present in all stages of secretory activity, attaining their maximum size about the time the cytoplasmic granules begin to disappear. The chromatin, scanty at all times in comparison with $Z e a$, shows slight changes in quantity analogous to those occurring in $Z e a$.

In the secreting cells of $Z e a$ the greatest apparent activity was reached when the nucleoli had disappeared and the chromatin had greatly increased. When the activity ceased, there was a formation of large nucleoli simultaneous with a disappearance of chromatin (Fig. 8). When the activity of secreting cells was checked by means of low temperature, it was found that the chromatin disappeared and large nucleoli were formed.

If these facts be interpreted to mean that there is some kind of relationship existing between the chromatin and nucleolus, such as has been postulated by Rosen ('95), Dixon ('99), van Wisselingh ('00), Gardner ('01), and others, then the difference between chromatin and nucleolus appears to be one of degree rather than of kind. The observations would seem to indicate that the material in the form of nucleoli was in a less active state than when in the form of chromatin, and as the cell-metabolism increased the latent substances became active.

Our ideas of the relations of the nucleolus to the other constituents of the cell are, as yet, entirely hypothetical. There are opportunities for studying the nucleolus of secreting-cells which seem capable of yielding better results than those hitherto obtained during the process of mitosis, because the former are performing their normal metabolism instead of being interrupted by the process of division.

The fact that these cells are both absorbing and secreting organs gives added importance to a point raised by Rosenberg ('99) concerning the causes for an increase of chromatin during secretory activity. He thought it might follow either as the result of the formation of an enzyme or as the result of absorbing abundant nutrition. The ease with which the scutellum of Zea may be separated from the endosperm suggests an experiment (which, 
unfortunately, has not been performed) for determining which of the two hypotheses (if either) is correct.

Concerning the nature of the various granules in the cells little can be said with any degree of certainty. They appear to arise as products of cellular activity, yet Müller ('96) believes that they are the elementary organs of the cell and are capable of growth and division. It is hoped that a wider application of the methods of physiological chemistry will supplement the results thus far obtained by the methods of histology.

The extrusion of solid substance from the nucleus has been reported by many observers, but I have not been able to find any indications of it in my study. In every case it appeared as though the exchange of substances was accomplished when they were in a liquid state. It must be borne in mind that the soluble proteids would be precipitated by the reagents used in killing and dehydrating, and therefore granules in the prepared sections are not necessarily indicative of their presence in the living cell.

Throughout the progress of the work I have been impressed by the similarities between enzymes and protoplasm in their manner of origin, action, and ultimate dissolution. Many of the similarities have been pointed out by Bokorny ('00). The two substances react similarly to most stimuli, except that enzymes show a greater resistance to destructive agents such as temperature, light, chemicals, \&c. The decomposition of certain substances, e. g. sugar, by enzymes and protoplasm is very similar.

The passage of two currents through the epidermal cells, one toward the endosperm and one toward the seedling, is undoubtedly brought about by osmosis modified by the selective action of the protoplasmic membrane. The existence of starch in the scutellum of Zea Mais shows that very little diastase passes toward the young plant.

\section{Summary.}

I. The results obtained in fixed and stained material are dependent to some extent upon the technique.

2. In the resting condition the secreting-cells of both $Z e a$ and Phoenix are crowded with relatively small proteid granules. As secretion begins these granules gradually disappear. In $Z e a$ this disappearance coincides closely with the consumption of the endosperm ; in Phoenix, however, the granules disappear long before the endosperm is dissolved.

3. The chromatin of the nuclei is small in amount at the beginning of secretion and increases as germination progresses. The nucleolus diminishes in size as germination progresses. These changes are more noticeable in the case of Zea than in Phoenix.

4. There is no evidence that solid matter is extruded from the nucleus.

5. At the close of secretory activity the protoplasm of the secretingcells breaks down and the products of disintegration disappear from sight. 


\section{BIBLIOGRAPHY.}

An asterisk denotes that $I$ have not examined the original paper.

BOKORNy ('00): Empfindlichkeit der Fermente: Bemerkungen über die Beziehung derselben zu dem Protoplasma. Chemiker-Zeitung, I900.

BRown and Escombe ('88): On the depletion of the endosperm of Hordeum vulgare during germination. Proc. Roy. Soc. lxiii, 3, I888.

BRown and MORRIS ('90): On the germination of some of the Gramineae. Jour. Chem. Soc. Trans. lvii, $45^{8}, 1890$.

Correns ('96): Zur Physiologie von Drosera rotundifolia. Bot. Zeit., 1896.

DARWIN, C. ('75): Insectivorous Plants. London, I 875.

DARwin, F. ('76): The process of aggregation in the tentacles of Drosera rotundifolia. Quart. Jour. Micr. Sci., N. S., xvi, 3०9, 1876.

('77): On the protrusion of protoplasmic filaments from glandular hairs on the leaves of the common teasel. Quart. Jour. Micr. Sci., N. S., xvii, 1877 .

('78): Experiments on the nutrition of Drosera rotundifolia. Jour. Linn. Soc. Bot., xvii, 17,1878 .

De Fries ('86): Ueber die Aggregation im Protoplasma von Drosera rotundifolia. Leipzig, 1886.

Dixon ('99): The possible function of the nucleolus in heredity. Ann. Bot., xiii, 269, I899.

*Fischer, R. H. ('03) : Ueber Enzymwirkung und Gärung. Sep.-Abdr. a. d. Sitzungsber. d. Niederrheinischen Gesells. für Natur- und Heilkunde. Bonn, 1903.

FromanN ('84): Untersuchungen über Struktur, Lebenserscheinungen und Reactionen thierischer und pflanzlicher Zellen. Jenaische Zeit., xvii, 1, 1884 .

Gardiner ('83): On the changes in the gland cells of Dionaea muscipula during secretion. Proc. Roy. Soc., xxxvi, 180,1883 .

('85): On the phenomena accompanying stimulation in the gland cells of Drosera dichotoma. Proc. Roy. Soc., xxxix, 229, 1885.

Gardner ('01): Studies on growth and cell division in Vicia Faba. Contributions from the Bot. Lab. of the Univ. of Pennsylvania, ii, No. 2, 1901.

Garnier ('00): De la structure et du fonctionnement des cellules glandulaires séreuses. Jour. de l'Anat., xxxvi, 22, 1900.

Grüss ('93) : Ueber den Eintritt von Diastase in das Endosperm. Ber. d. d. Bot. Ges., xi, 286, I 893.

- ('94): Ueber die Einwirkung der Diastase auf Reservecellulose. Ibid., xii, 60, I894.

('97): Ueber die Secretion des Schildchens. Jahrb. wiss. Bot., xxx, 645, 1897 .

('99): Beiträge zur Enzymologie. Festschrift für Schwendener, I899.

('02): Ueber den Umsatz der Kohlenhydrate bei der Keimung der Dattel. Ber. d. d. Bot. Ges., $x x, 36,1902$.

Haberlandt ('87): Ueber die Beziehung zwischen Function und Lage des Zellkernes bei den Pflanzen. Jena, 1887.

Hansteen ('94): Ueber die Ursachen der Entleerung der Reservestoffe aus Samen. Flora, lxxix, $4 \mathrm{I} 9, \mathrm{I} 894$.

HARPer ('99): Cell division in sporangia and asci. Ann. Bot., xiii, 467, I899.

How ARD ('03): Journal of Applied Microscopy and Laboratory Methods, vi, p. 2498, 1903.

HUIE ('97): Changes in the cell organs of Drosera rotundifolia produced by feeding with eggalbumen. Quart. Jour. Micr. Sci., N.S., xxxix, 387, I897.

('99): Further study of cytological changes produced in Drosera. Ibid., xlii, 203, 1899.

Klebs ('88): Beiträge zur Physiologie der Pflanzenzelle. Unters. a. d. Inst. zu Tübingen, ii, 489, r888.

Korscheldt ('89) : Beiträge zur Morphologie und Physiologie des Zellkernes. Zool. Jahrb., Abth. für Anat. iv, I, I89I.

Macfarlane, ('01): Current problems in plant cytology. Contributions from the Bot. Lab. of the Univ. of Pennsylvania, ii, No. 2, 183, r 901 .

Mathews ('99): The changes in the structure of the pancreas cell. Jour. Morph., xv, i 899, Supplement.

MONTGOMERy ('99): Comparative cytological studies with especial regard to the morphology of the nucleolus. Jour. Morph., xv, 265,1899 .

MÜller ('96): Drüsenstudien, I. Arch. f. Anat. u. Physiol. Anat., I896.

('98): Drüsenstudien, II. Zeitsch. f. wiss. Zool., lxiv, I898. 
PURIEwitsch ('98): Physiologische Untersuchungen über die Entleerung der Reservestoffbehälter.

Jahrb. wiss. Bot., xxxi, I, 1898 .

Rosen ('95): Beiträge zur Kenntniss der Pflanzenzellen. Cohn's Beiträge, vii, 225, I895.

Rosenberg ('99): Physiologisch-cytologische Untersuchungen über Drosera rotundifolia. Upsala, I 899 .

Schimper ('82): Notizen über insectenfressende Pflanzen. Bot. Zeit., I882.

*Schniewind-Thies ('97): Beiträge zur Kenntniss der Septalnectarien. Jena, 1897.

TIMBERLAKe ('01): Starch formation in Hydrodictyon utriculatum. Ann. Bot., xv, 619, 1901.

TORREY ('02); Cytological changes accompanying the secretion of diastase. Bull. Torrey Bot. Club, xxix, 421,1902 .

Townsend ('97): Der Einfluss des Zellkernes auf die Bildung der Zellhaut. Jahrb. wiss. Bot., xxx, $484,1897$.

Van Gehuchten ('90): Le mécanisme de la sécrétion. Anat. Anzeig., r, I891.

Van Wisselingh ('00): Ueber Kerntheilung bei Spirogyra. Flora, lxxxvii, 355, 1900.

Zimmermann ('93): Botanical Microtechnique. (Trans. by Humphrey, New York, I 893.) ('96): Die Morphologie und Physiologie des pflanzlichen Zellkernes. Jena, $\mathbf{1 8 9 6 .}$

\section{EXPLANATION OF FIGURES IN PLATE XX.}

Illustrating Mr. Reed's paper on Enzyme-secreting Cells.

All figures were drawn with Abbés camera lucida, Zeiss I/I 6 oil immersion objective, and compensating oculars $8, \mathrm{I} 2$, and $\mathbf{1} 8$. Figs. I- 8 were drawn from the epidermal cells of the scutellum of Zea Mais. Figs. 9-1 3 were drawn from the epidermal cells of the absorbing organ of Phoenix dactylifera.

Fig. I. Nucleus in the resting condition. Saturated solution of mercuric bichloride. Kleinenberg's Haematoxylin. $\times$ I $55^{\circ}$.

Fig. 2. Cell after absorbing water for three hours. Mann's Picro-corrosive killing fluid. Mann's Eosin-Toluidin Blue. $\times$ I $55^{\circ}$.

Fig. 3. Cell after thirty hours' activity. Worcester's killing fluid. Mann's Eosin-Toluidin Blue. $\times$ I550.

Fig. 4. Nucleus after forty-eight hours' activity. Worcester's killing fluid. Mann's EosinToluidin Blue. $\times 155^{\circ}$.

Fig. 5. An unusually swollen nucleus after three days of activity. Worcester's killing fluid. Mann's Eosin-Toluidin Blue. $\times \mathbf{r}_{55}$.

Fig. 6. Normal nucleus after three days of activity. Worcester's killing fluid. Mann's EosinToluidin Blue. $\times 1550$.

Fig. 7. Cell after eight and one-half days of activity. Worcester's killing fluid. Mann's Eosin-Toluidin Blue. $\times 1600$.

Fig. 8. Cell after thirteen days of activity. Worcester's killing fluid. Mann's Eosin-Toluidin Blue. $\times 1600$.

Fig. 9. Cell after six days of activity. Worcester's killing fluid. Kleinenberg's Haematoxylin. $\times 155^{\circ}$.

Fig. I0. Cell after fourteen days of activity. Worcester's killing fluid. Kleinenberg's Haematoxylin. $\times \mathrm{I}_{55}$.

Fig. I1. Cell after eighteen days of activity. Worcester's killing fluid. Mann's Eosin-Toluidin Blue. $\times 1550$.

Fig. I2. Cell after twenty-six days of activity. Mann's Picro-corrosive fluid. Kleinenberg's Haematoxylin. $\times 155^{\circ}$.

Fig. I3. Cell after thirty-three days of activity. Worcester's killing fluid. Flemming's triple stain. $\times 155^{\circ}$. 

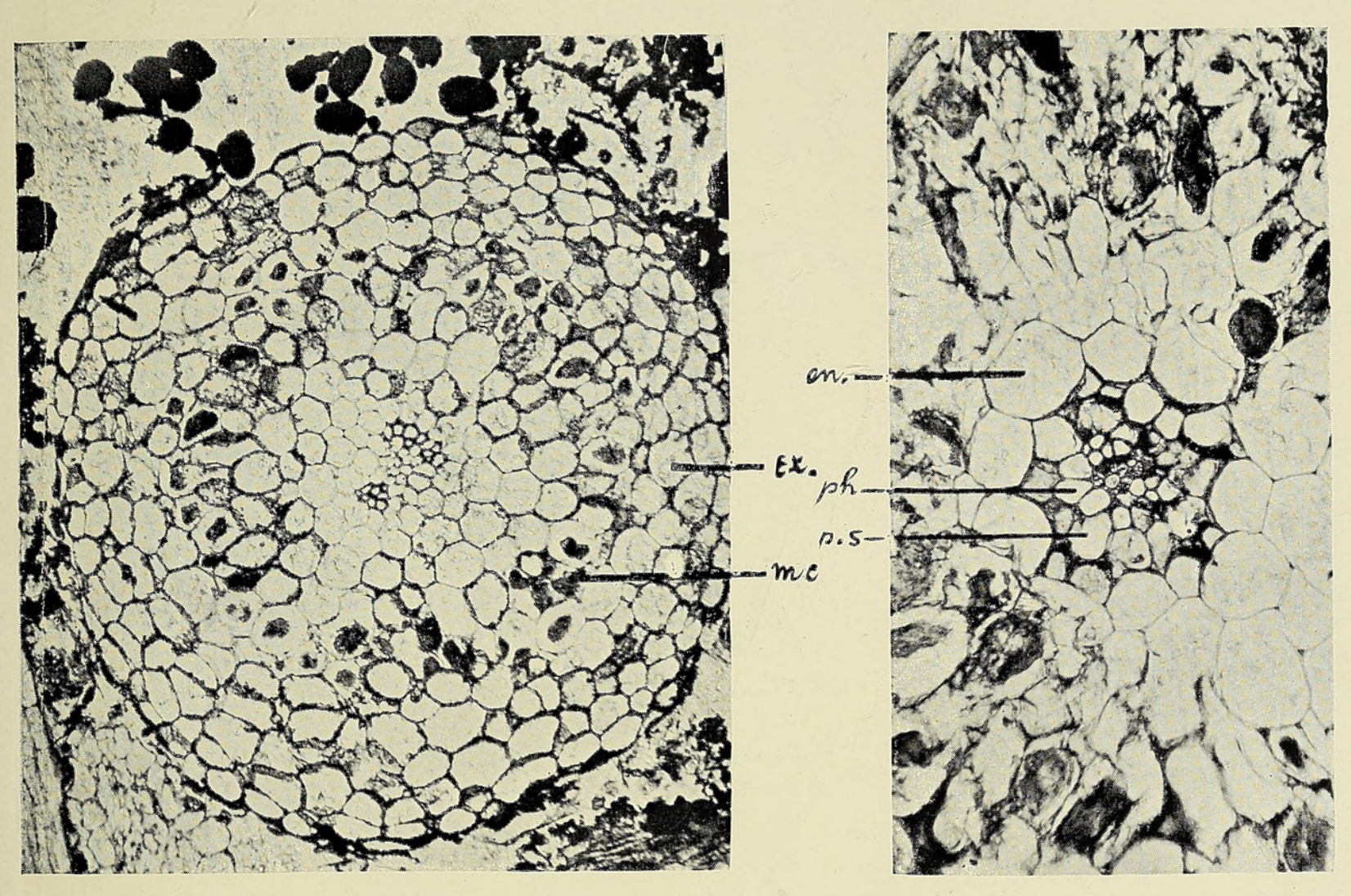

3.
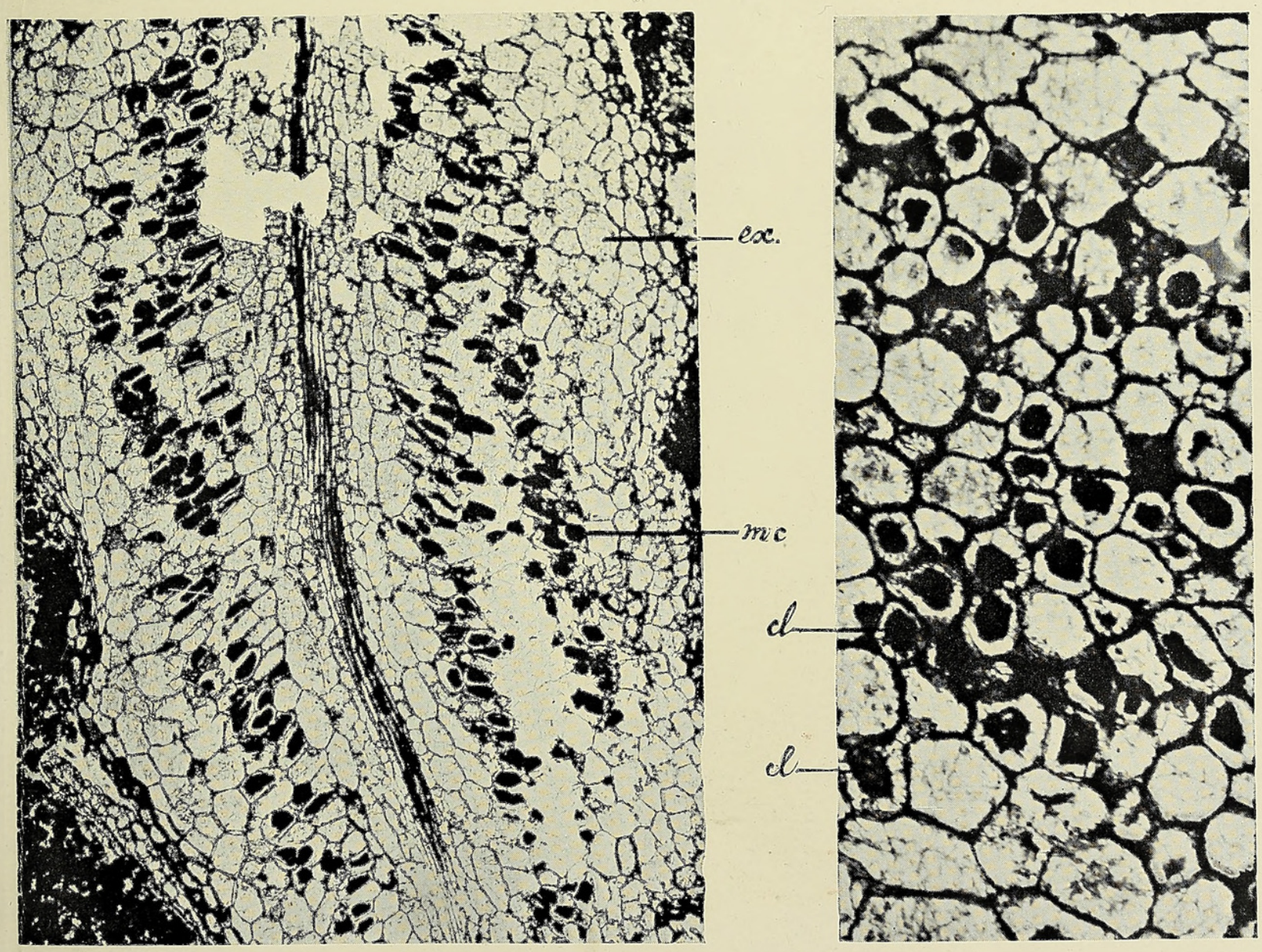


\section{$2 \mathrm{BHL}$ Biodiversity Heritage Library}

Reed, Howard S . 1904. "A study of the enzyme-secreting cells in the seedlings of Zea mais and Phoenix dactylifera." Annals of botany 18, 267-287. https://doi.org/10.1093/oxfordjournals.aob.a088962.

View This Item Online: https://www.biodiversitylibrary.org/item/234469

DOI: https://doi.org/10.1093/oxfordjournals.aob.a088962

Permalink: https://www.biodiversitylibrary.org/partpdf/318760

\section{Holding Institution}

Smithsonian Libraries

\section{Sponsored by}

Biodiversity Heritage Library

\section{Copyright \& Reuse}

Copyright Status: Not in copyright. The BHL knows of no copyright restrictions on this item.

This document was created from content at the Biodiversity Heritage Library, the world's largest open access digital library for biodiversity literature and archives. Visit BHL at https://www.biodiversitylibrary.org. 